\title{
Article
}

\section{Effect of Moringa oleifera supplementation during pregnancy on the prevention of stunted growth in children between the ages of 36 to 42 months}

\author{
Hasan Basri, ${ }^{1}$ Veni Hadju, ${ }^{2}$ Andi Zulkifli, ${ }^{3}$ Aminuddin Syam, ${ }^{2}$ Rahayu Indriasari2 \\ ${ }^{1}$ Doctoral student in Nutrition Science, School of Public Health, Hasanuddin University, Makassar; ${ }^{2}$ Department \\ of Nutrition Science, School of Public Health, Hasanuddin University, Makassar; ${ }^{3}$ Department of Epidemiology, \\ School of Publlic Health, Hasanuddin University, Makassar, Indonesia
}

\begin{abstract}
Background: The government has made provisions to improve the nutrition of stunted children under the age of five nationally by providing iron folic acid (IFA) tablet since conception. However, these drugs were not able to reduce the incidence of stunted growth. The aim of this study is to assess the effect of moringa intervention during pregnancy on the incidence of stunted growth in children between the ages of 36 to 42 months.

Design and Methods: This study is a follow-up to an experimental RCT-DB study during pregnancy. The interventions given were PG (Moringa Flour), EG (Moringa Extract) and IG (IFA) which was used as control.

Results: The highest number of children that had stunted growth after taking the PG by IG and EG extracts were 66 $(41.5 \%), 53(33.3 \%)$ and $40(25.2 \%)$, respectively. The stunted risk factor analysis did not show a significant relationship to the stunted incidence. Furthermore, the consumption and dietary patterns of children were based on only fat consumption which was associated with stunted incidence $(\mathrm{p}<0.05)$. The results of multivariate analysis showed that the EG extract was effective in reducing the incidence of stunted growth $(\mathrm{p}<0.005)$ and as a protective factor of 0.431 times the incidence of stunted growth (LL$\mathrm{UL}=0.246-0.754)$.

Conclusions: The administration of Moringa oleifera extract during pregnancy prevents the incidence of stunted growth in children.
\end{abstract}

\section{Introduction}

Stunting is still a problem of international and national nutritional health, and every year 3 million deaths are recorded in children due to malnutrition. Previous record have shown that around 150.8 million children suffer from stunted growth, ${ }^{1}$ and this was found in most African countries and Southeast Asia region.
Furthermore, the stunting rate in the South and Southeast Asia region is $55.9 \%$ and $39.40 \% .^{2}$ Based on the basic health research survey that was conducted in 2018 , it was reported that $30.8 \%$ of children under the age of five suffered from stunted growth in Indonesia. Furthermore, the highest prevalence of stunted growth in Indonesia was found in the East Nusa Tenggara province with $69.6 \%$. The stunting rate in South Sulawesi Province was still very high with $35.7 \%$ and it was ranked the 4 th highest national stunted growth prevalence. ${ }^{3}$ The Research data from several districts showed that the prevalence of stunted growth in Sulawesi states varies greatly, with the Malili and Jeneponto districts having $22.1 \%$ and $44 \%$ in $2018.4,5$ However, it was generally concluded that the problem of stunted growth in South Sulawesi is still high.

Stunted growth reduction programs such as providing interventions during the period of preconception, pregnancy, and breastfeeding have been implemented in many developing countries. This was carried out by improving the quality of breastfeeding mother's before providing supplementation for 2 years old children. The ingredients of the intervention are in various types ranging from chemical properties to supplementations using local food ingredients. Though the results of these nutritional interventions have not shown consistent results, they have been able to reduce the prevalence of stunted growth in developing countries.

The prevention of stunted growth needs to be carried out before conception because it is a chronic nutritional problem. Previous research has shown that nutritional improvement interventions during the period of pregnancy are effective in improving the nutritional status of children under the age of five. ${ }^{6}$ The government also has made improvements to the national nutrition intake of children through the provision of iron folic acid (IFA) tablets during pregnancy. However, this intervention has not been able to reduce the prevalence of anemia in pregnant women and stunted growth in children in Indonesia. Therefore, it is necessary to have an alternative nutritional intervention that reduces the prevalence of anemia in pregnant women and stunted growth in children. One of the local foods in Indonesia that has abundant nutrients is Moringa oleifera. ${ }^{7}$ Moringa could be used as a local

Significance for public health

Nutrition interventions to improve maternal and child health is a top priority in the field of public health sciences. These interventions are urgently needed to improve the nutritional intake of pregnant women and children; however, they should be affordable and appropriate. The prevalence of stunted growth in Indonesia is still a major problem that need to be solved. Administering moringa extract to pregnant women would have a good impact on both the mother and child. In this study, it was shown that the administration of this extract during pregnancy reduced the incidence of stunted growth for children between 
food-based nutritional supplement for pregnant women in reducing the prevalence of anemia and stunted growth in children., 8 Previous studies have shown that giving moringa to pregnant women increases the level of iron in their body. It was also shown that intake of moringa prevents anemia, improves the quantity of breastfeeding mother, reduce stress and increases the body weight of pregnant women. ${ }^{10,11}$

The results of previous study showed the various effect of moringa intervention on children between the ages of 6 to 24 months. For the PG intervention ( $p>0.005)$, children at the age of six had the highest prevalence of stunted growth with a total number of $44(42.7 \%)$. While for the EG intervention ( $p>0.005)$, children at the age of 12 months had the highest prevalence of stunted growth with a total number of $29(30.9 \%)$. Furthermore, children at the age 24 months showed that PG intervention was the highest stunted prevalence which is 57 (48.7) with $\mathrm{p}>0.05 .5,12,13$ To sum up that study, 0 to 24 months of age showed no consistent intervention effect on stunted incidence. Therefore, this study assesses the effect of moringa intervention during pregnancy on the incidence of stunted growth in children between the ages of 36 to 42 months.

\section{Design and Methods}

This is a follow-up study of an experimental randomized control trial-double blind (RCT-DB) study that was conducted during pregnancy. ${ }^{14}$ This study was conducted in 6 sub-districts, namely Bangkala, Tamalatea, Bontoramba, Binamu, Kelara and Tarowang in Jeneponto District, South Sulawesi, Indonesia. There were 3 forms of capsules that were used, and they include powder Moringa (PG) $500 \mathrm{mg}$, extract Moringa (EG) $500 \mathrm{mg}$ and iron folic $\mathrm{acid} / \mathrm{Fe} 60 \mathrm{mg}+0.2$ folic acid, which was used as the control (Tablet Tambah Darah). "Tablet Tambah Darah/TTD” was part of the government program in improving the nutritional status of mothers and children and was used as a control for comparing the effects of the interventions. The intervention was carried out in third trimester pregnant women that met the inclusion and exclusion criteria, daily for 90 days. The number of pregnant women that survived and were able to give birth was 440 (single wombs). However, in the age range of children between 0 to 36 months, the respondents pulled out of the research leaving the total number of children that survived to 340 children. This was caused by immigration parents their brought their children to work in urban areas or overseas. Birth history, breastfeeding and complementary feeding data were used from the follow-up results in previous studies starting from 0 to 2 years old. ${ }^{5}$

This study received Ethical Approval from the Ethics Commission of the Faculty of Public Health, Hasanuddin University with Protocol Number: 5111993028. Furthermore, the height, weight, food intake and children's diet were measured and collected by enumerators that have been trained. Measurement of height and body weight was carried out using a microtoise and a digital scale standardized by the Ministry of Health, Republic of Indonesia. The measurement of the children's food intake was carried out using the 24-hour Recall Method and was then converted into nutrients using the Nutrisurvey 2007 app. Furthermore, the children's dietary patterns were measured using the Food Frequency Questionnaires FFQ () in children aged 36-42 months. The determination of the HAZ category was carried out using the WHO Anthro 2005 apps and data was analyzed using SPSS 25 for Mac.

\section{Results and Discussions}

The children between the ages of 34 to 39 months had the highest number in the EG group with a total of 77 (46.1\%), while those between the ages of 40 to 44 months were in the IG group with a total number of $70(43.5 \%)$. The bivariate analysis showed that the intervention group was related to the age children group

Table 1. Characteristics of children based on the intervention group.

\begin{tabular}{|c|c|c|c|c|}
\hline Variables & PG (\%) & IG (\%) & EG (\%) & p \\
\hline $\begin{array}{l}\text { Age } \\
\qquad \begin{array}{l}34-39 \text { months } \\
40-44 \text { months }\end{array}\end{array}$ & $\begin{array}{l}46(27.5) \\
66(41)\end{array}$ & $\begin{array}{l}44(26.3) \\
70(43.5)\end{array}$ & $\begin{array}{l}77(46.1) \\
25(15.5)\end{array}$ & 0.000 \\
\hline $\begin{array}{l}\text { Sex } \\
\text { Male } \\
\text { Female }\end{array}$ & $\begin{array}{l}56(33.1) \\
56(35.2)\end{array}$ & $\begin{array}{l}63(37.3) \\
51(32.1)\end{array}$ & $\begin{array}{l}50(29.6) \\
52(32.7)\end{array}$ & 0.607 \\
\hline $\begin{array}{l}\text { Birth weight } \\
\text { Low birth weight } \\
\text { Normal }\end{array}$ & $\begin{array}{c}0.245 \\
2(15.4) \\
110(34.9)\end{array}$ & $\begin{array}{l}7(53.8) \\
107(34)\end{array}$ & $\begin{array}{c}4(30.8) \\
98(31.1)\end{array}$ & \\
\hline $\begin{array}{l}\text { Birth length }(\mathrm{cm}) \\
\quad<48 \\
\geq 48\end{array}$ & $\begin{array}{l}16(25.4) \\
96(36.2)\end{array}$ & $\begin{array}{l}27(42.9) \\
87(32.8)\end{array}$ & $\begin{array}{l}20(31.7) \\
82(30.9)\end{array}$ & 0.199 \\
\hline $\begin{array}{l}\text { Breastfeeding first } 6 \text { months } \\
\text { Non-exclusive } \\
\text { Exclusive }\end{array}$ & $\begin{array}{l}48(33.8) \\
64(34.4)\end{array}$ & $\begin{array}{l}48(33.8) \\
66(35.5)\end{array}$ & $\begin{array}{l}46(45.1) \\
56(30.1)\end{array}$ & 0.901 \\
\hline $\begin{array}{l}\text { Complementary feeding } \\
\quad<6 \text { months } \\
\geq 6 \text { months }\end{array}$ & $\begin{array}{l}26(33.8) \\
86(34.3)\end{array}$ & $\begin{array}{l}23(29.9) \\
91(36.3)\end{array}$ & $\begin{array}{l}28(36.4) \\
74(29.5)\end{array}$ & 0.451 \\
\hline $\begin{array}{l}\text { Immunization } \\
\text { Incomplete } \\
\text { Complete }\end{array}$ & $\begin{array}{l}50(29.8) \\
62(38.8)\end{array}$ & $\begin{array}{l}63(37.5) \\
51(31.9)\end{array}$ & $\begin{array}{l}55(32.7) \\
47(29.4)\end{array}$ & 0.225 \\
\hline
\end{tabular}

PG, powder Moringa $500 \mathrm{mg}$; EG, extract Moringa $500 \mathrm{mg}$; IG, iron folic acid/Fe $60 \mathrm{mg}+0.2$ folic acid. 
( $p<0.001)$. However, the birth weight and length, excluding the breastfeeding and complementary feeding did not show a significant relationship with the intervention group ( $p>0.05)$ (Table 1).

Table 2 shows the highest number of stunted growth in children in the PG intervention group witha total number of 66 $(41.5 \%)$, while the IG and EG groups were 53 (33.3\%) and 40 $(25.2 \%)$. The test results showed a significant relationship between the intervention group and the incidence of stunted growth in children $(p<0.05)$. Other variables which are risk factors for incidence of stunted growth did not show a significant relationship in this study $(\mathrm{p}>0.05)$.

Table 3 shows that the energy intake of stunted children was lower than normal which are $981 \pm 455 \mathrm{kcal}$ and $1062 \pm 520 \mathrm{kcal}$. The results showed that their energy intake was not related to the

Table 2. Analysis of factors associated with the stunted incidence.

\begin{tabular}{|c|c|c|c|}
\hline Variables & & & p \\
\hline & Stunted (\%) & Normal (\%) & \\
\hline Intervention group & & & \\
\hline PG & $66(41.5)$ & $46(27.2)$ & 0.014 \\
\hline IG & 53 (33.3) & $61(36.1)$ & \\
\hline EG & $40(25.2)$ & $62(36.7)$ & \\
\hline Age & & & \\
\hline 34-39 months & $82(49.1)$ & $85(50.9)$ & 0.817 \\
\hline 40-44 months & $77(47.8)$ & $84(52.2)$ & \\
\hline Sex & & & \\
\hline Male & $87(51.5)$ & $82(48.5)$ & 0.262 \\
\hline Female & $72(45.3)$ & $87(54.7)$ & \\
\hline Weight birth & & & \\
\hline Low birth weight & $6(46.2)$ & $7(53.8)$ & 0.864 \\
\hline Normal & $153(48.6)$ & $162(51.4)$ & \\
\hline Length birth & & & \\
\hline$<48$ & $33(52.4)$ & $30(47.6)$ & 0.490 \\
\hline$\geq 48$ & $126(47.5)$ & $139(52.5)$ & \\
\hline Breastfeeding & & & \\
\hline Non-exclusive & $70(49.3)$ & $72(50.7)$ & 0.795 \\
\hline Exclusive & $89(47.8)$ & $97(52.2)$ & \\
\hline Complementary feeding & & & \\
\hline$<6$ months & $35(45.4)$ & $42(54.4)$ & 0.544 \\
\hline$\geq 6$ months & $124(49.4)$ & $127(50.6)$ & \\
\hline Immunization & & & \\
\hline Incomplete & $79(47.0)$ & $89(53.0)$ & 0.590 \\
\hline
\end{tabular}

incidence of stunted growth ( $p>0.05)$. Furthermore, it showed that the highest fat intake in normal children was more compared to stunted children, namely $32 \pm 25 \mathrm{mg}$ and $27 \pm 18$. Other nutrient intake showed no significant relationship with the incidence of stunted growth $(\mathrm{p}>0.05)$. Furthermore, all the types of food pattern in children showed no significant relationship to the incidence of stunted growth. Multivariate analysis was conducted to see the effect and significant value of RR (Relative Risk) between the intervention groups and the decrease in the incidence of stunted growth. Furthermore, it also includes other variables that are risk factors for stunted growth incidence. In the intervention group using IG as the reference showed that the EG group had a $p<0.005$. This means that the EG intervention had an effect on reducing the incidence of stunted growth (Table 4).

Table 3. Analysis bivariate between food intake of child and stunted.

\begin{tabular}{|c|c|c|c|}
\hline \multirow[t]{2}{*}{ Food intake } & \multicolumn{2}{|c|}{ HAZ } & \multirow[t]{2}{*}{ p } \\
\hline & $\begin{array}{c}\text { Stunted } \\
(\overline{\mathbf{x}} \pm \text { SD }) /(\%)\end{array}$ & $\begin{array}{c}\text { Normal } \\
(\overline{\mathbf{x}} \pm \text { SD }) /(\%)\end{array}$ & \\
\hline Energy & $965 \pm 413$ & $1062 \pm 520$ & 0.065 \\
\hline Carbohydrate & $145 \pm 69$ & $150 \pm 76$ & 0.528 \\
\hline Fat & $27 \pm 18$ & $32 \pm 25$ & 0.039 \\
\hline Protein & $34 \pm 21$ & $37 \pm 20$ & 0.156 \\
\hline $\mathrm{Zn}$ & $6.25 \pm 3.72$ & $3.84 \pm 2.46$ & 0.402 \\
\hline $\mathrm{Fe}$ & $5.58 \pm 2.48$ & $3.59 \pm 3.15$ & 0.301 \\
\hline Folic acid & $70 \pm 57$ & $68 \pm 45$ & 0.764 \\
\hline Vitamin C & $18 \pm 25$ & $21 \pm 34$ & 0.389 \\
\hline $\begin{array}{l}\text { Milk intake } \\
\text { Low } \\
\text { Enough }\end{array}$ & $\begin{array}{l}106(47.5) \\
53(50.5)\end{array}$ & $\begin{array}{l}117(52.5) \\
52(49.5)\end{array}$ & 0.619 \\
\hline $\begin{array}{l}\text { Egg intake } \\
\text { Low } \\
\text { Enough } \\
\end{array}$ & $\begin{array}{c}45(39.8) \\
114(53.0)\end{array}$ & $\begin{array}{c}68(60.2) \\
101(47.0)\end{array}$ & 0.230 \\
\hline $\begin{array}{l}\text { Fish intake } \\
\text { Low } \\
\text { Enough }\end{array}$ & $\begin{array}{c}19(47.5) \\
140(48.6)\end{array}$ & $\begin{array}{c}21(52.5) \\
148(51.4)\end{array}$ & 0.895 \\
\hline $\begin{array}{l}\text { Vegetable intake } \\
\text { Low } \\
\text { Enough } \\
\end{array}$ & $\begin{array}{c}26(34.2) \\
133(52.8)\end{array}$ & $\begin{array}{c}50(65.8) \\
119(47.2)\end{array}$ & 0.650 \\
\hline $\begin{array}{l}\text { Fruit intake } \\
\text { Low } \\
\text { Enough } \\
\end{array}$ & $\begin{array}{l}94(49.7) \\
65(46.8)\end{array}$ & $\begin{array}{l}95(50.3) \\
74(53.2)\end{array}$ & 0.594 \\
\hline
\end{tabular}

HAZ, height of age Z score.

Table 4. Multivariate analysis of factors affecting the stunted incidence.

\begin{tabular}{lcccc} 
Variables & $\mathrm{p}$ & $\mathrm{RR}$ & Lower limit & 95\% CI \\
& & & & \\
Upper limit \\
Intervention & & & 0.246 & 0.754 \\
$\quad$ EG & 0.003 & 0.431 & 0.428 & 1.289 \\
$\quad$ PG & 0.291 & 0.743 & Ref & 3.884 \\
WG & Ref & 1 & 0.377 & 1.297 \\
\hline Leight birth $(<2500 \mathrm{gr})$ & 0.750 & 1.209 & 0.408 & 1.449 \\
Breastfeeding $(\mathrm{no})$ & 0.281 & 0.727 & 0.505 & 2.347 \\
Complementary feeding $(<6$ months) & 0.561 & 0.855 & 0.687 & 1.707 \\
Immunization & 0.446 & 1.270 & 0.694 & 1.108 \\
\hline Mother height & 0.711 & 1.089 & 0.392 & 1.004 \\
Fat consumption & 0.116 & 0.659 & 0.310 & \\
\hline
\end{tabular}

PG, powder Moringa $500 \mathrm{mg}$; EG, extract Moringa $500 \mathrm{mg}$; IG, iron folic acid/Fe $60 \mathrm{mg}+0.2$ folic acid. 
This study shows that EG intervention has a significant effect on reducing the incidence of stunting in children between the ages of 36 to 42 months. The EG intervention showed the lowest prevalence of stunting among other interventions such as the PG and IG. The EG intervention is moringa that was made through the extraction process. While the PG intervention is moringa that was made traditionally by drying the leaves and pounding until it was smooth. During pregnancy, mothers need to get an adequate supply of nutrients to improve their health status and also the growth of the fetus. ${ }^{15}$ Giving moringa extract to pregnant women provides an abundant supply of micronutrients including $\mathrm{Fe}$, vitamin $\mathrm{A}$, vitamin $\mathrm{C}$, and selenium during pregnancy. It was known that moringa plants have a lot of micronutrient and macronutrient nutrients, therefore the researchers named it the miracle of the tree. ${ }^{7}$

Most of the pregnant women were deficient in micronutrient nutrients compared to macronutrients during pregnancy. Moringa extract has sufficient micronutrients compared to TTD, therefore mothers that consume moringa are filled with micronutrients. The role of micronutrients such as $\mathrm{Fe}$ in moringa extract provides increased hemoglobin in pregnant women and also prevent DNA damage due to oxidative stress. ${ }^{11}$ A study conducted by Sindhu showed that there was a significant increase in the hemoglobin level of anemic pregnant women that were given moringa extract. Therefore, the study recommended the administration of moringa to prevent iron deficiency in anemic pregnant women. ${ }^{16}$

Moringa extract has active chemical substances (phytochemicals) in the form of flavonoids, phytosterols, and steroids which have anti-inflammatory, anti-carcinogenic, anti-proliferative, and anti-viral functions. ${ }^{17,18}$ The content of these phytochemicals in this extract protects the mother from diseases that could interfere with fetal growth during pregnancy. Therefore, administering moringa extracts improve the nutritional status of mothers and affects the placentation and supply of nutrients from the mother to the fetus. ${ }^{19,20}$

Improving maternal health during pregnancy provides a positive response to fetal growth because healthy children are born to healthy mothers. ${ }^{21}$ Previous studies have suggested that the administration of moringa extracts during pregnancy would prevent children from low birth weight. ${ }^{11}$ This occurred because during pregnancy the mother had a good supply of micronutrients from moringa which has a function to increase the growth of important organs in the fetal phase. Furthermore, the child's growth was strongly influenced by the mother's nutrient intake in this phase. Whenever the mother's nutritient level is sufficient, the child gets enough nutrients through the mother's placenta. $^{22}$

Apart from pregnant women, the administration of moringa to children also shows good results on their nutritional status during the toddler phase. The nutrients in moringa are rich in protein, $\mathrm{Ca}, \mathrm{Fe}$, vitamin $\mathrm{C}$, and carotene, and could be used as a suitable plant in areas with high prevalence of malnutrition. ${ }^{23}$ Previous studies have shown that the administration of moringa could overcome the incidence of malnutrition for children in their first year. ${ }^{24}$ Furthermore, a research conducted by Andrew in the Arusha region, showed that the use of moringa has a significant positive effect on the nutritional status of children and was also able to reduce their morbidity. ${ }^{25}$ This happens because the vitamin $\mathrm{C}$ and $\mathrm{Fe}$ in moringa plays a role in antioxidant function, which include preventing free radicals that would disrupt the nutritional status of children. Also, iron and other micronutrients play a role in increasing hemoglobin levels in children. Srikanth's research in India stated that giving moringa to children could also be an alternative in treating protein deficiency. ${ }^{26}$ This shows the contribution of the abundant amount and function of the protein in Moringa plants. This study also shows that there was no difference in the average consumption pattern of vegetables and fruit in each intervention group. Therefore, this supports an important role in the availability of nutritional supplies of children from birth.

There was an average difference between the administration of EG, PG, and IG to reduce stunting in children. The multivariate analysis shows that the role of EG interventions is significant in reducing the incidence of stunting compared to other interventions. This is because in the IG intervention, the composition in it only consists of Fe and folic acid. When compared with EG intervention which has many abundant nutrients, not only $\mathrm{Fe}$ and folic acid. In terms of quantity, there was only 60 $\mathrm{mg}$ of Fe plus $0.2 \mathrm{mg}$ of folic acid in IG. While in EG, based on the results of laboratory tests at Gajah Mada University, Indonesia, it was stated that in $100 \mathrm{~g}$ of the extract there were $9.72 \mathrm{mg}$ of $\mathrm{Fe}, 1282 \mathrm{mg}$ of vitamin $\mathrm{C}$ and 12.31 grams of protein. This shows that in terms of nutritional availability between EG and IG, the nutritional adequacy of mothers that were given EG was better than IG. Therefore, children born in the EG intervention group were better at preventing stunting compared to IG.

Furthermore, the difference between EG and PG lies in the presentation of the moringa supplementation process where EG uses water extraction and encapsulates it, while PG uses a drying and refining process before being encapsulated. Based on previous research, it was shown that 100 grams of PG contain 27.10 grams of protein, 2.30 grams of fat, $16.30 \mathrm{mg}$ of vitamin A, $17.30 \mathrm{mg}$ of vitamin C, $28.20 \mathrm{mg}$ of Fe, 5.20 grams of $\mathrm{Zn}$, and no Se. ${ }^{7}$ Furthermore, for the EG content as previously stated, 100 gr EG contains 12.31 grams of protein, 18.62 grams of fat, 313 micro vitamin A, 1282 micro vitamin C, 9.72 grams of $\mathrm{Fe}, 3.77$ grams of $\mathrm{Zn}$ and $47 \mathrm{mg}$ of Selenium. Therefore, the nutritional content of $\mathrm{PG}$ is more than $\mathrm{EG}$ in the nutritional content of Protein, Fe, and Zn. However, EG provides an abundance of nutrients that are more numerous and varies, for example in fat, vitamin $A$, vitamin $C$, and selenium nutrients that are not found in PG. Based on the nutritional value, the nutrients in EG are more diverse compared to PG. The difference in nutrient content makes a significant effect on the growth of the fetus in children and during breastfeeding.

Furthermore, several research articles show that the extracted form has greater advantages than the flour form. In the process of obtaining nutrients in the form of flour during the extraction process, several phytochemicals were found in the extracted material. Phytochemicals are active chemicals contained in a plant. Based on previous research, it was shown that EG has phytochemical ingredients such as flavonoids, saponins, alkaloids, tannins, and phenols. ${ }^{19}$ These phytochemicals are of several benefits for humans. For example, flavonoids are found to have a large anti-oxidant function and increase urination and electrolyte excretion, which functions like potassium that absorbs electrolyte ions. ${ }^{27}$ In addition, the phenolic chemicals in moringa are multi-functional compounds that are useful for pregnant women and children in preventing cell damage, diseases and aging. ${ }^{28}$

Previous research also shows that giving EG to pregnant women increases the quantity of their breast milk. The presence of abundant fat in moringa contributes to the formation of fatty acids which are very beneficial for nursing mothers. These fatty 
acids include Arachidic Acid (AA), Alfa Linoleic Acid (ALA), and Linoleic Acid (LA). The interaction and conversion in the body between ALA and LA form the Docosahexaenoic Acid (DHA), while the conversion from LA forms AA. DHA and AA play a major role in the growth and development of body tissues in children during toddlerhood. Previous studies have showed that the levels of DHA and AA in EG intervention were greater than PG, namely DHA $=38.20 \mathrm{ph} / \mathrm{mL}, \mathrm{AA}=180.16 \mathrm{ug} / \mathrm{m}$ and $\mathrm{DHA}=33.37, \mathrm{AA}=176 \mathrm{ug} / \mathrm{m}$. Therefore, this made the nutrition intervention in the form of EG to become better at reducing the incidence of stunting than the other two interventions, namely PG and IG. ${ }^{29}$

The external and internal factors of children that could influence the relationship between the interventions and the incidence of stunting were also measured to control the effect of these factors. They are risk factors for stunting including a long history of birth weight and length, consumption patterns, and children's intake. Based on the data collected, this study showed that birth weight and length, and differences in the average history of breastfeeding and complementary feeding in each intervention group were not associated with the incidence of stunting. Apart from not giving a relationship to the incidence of stunting, this factor does not have a significant difference in the proportion of each intervention group. The amount of nutritional intake for children shows that only fat nutrients are associated with the incidence of stunting. However, after the multivariate analysis was carried out to control the confounding variables, it was found that fat consumption did not significantly influence the relationship between EG intervention and the incidence of child stunting. This explains that these risk factors do not provide a simultaneous relationship to the incidence of child stunting in this study.

A research on the nutritional supplementation in pregnant women has been carried out but the results of these interventions are still very mixed. In this 5-year study, various types of nutrition interventions were also carried out during pregnancy and there was a closer attention at the effects on the growth of children between the ages 0 to 5 years. However, there have been no significant result in reducing the incidence of stunting in children at the age of 36 to 42 months. ${ }^{30}$ Therefore, the results of this study could be a solution to the problem of the nutrition intake of children and mothers in areas that have a high prevalence of stunted growth and anemia.

\section{Conclusions}

Administering EG supplementation during pregnancy prevents stunting compared to IG and IFA in children between the ages of 36 to 42 months. Therefore, it is recommended that pregnant women should consume moringa during pregnancy.
Correspondence: Hasan Basri, Public Health Faculty, Hasanuddin University, Jl. Perintis Kemerdekaan Km.10 Tamalanrea Makassar South Sulawesi 90245, Indonesia.

Tel. +62.411585658 - Fax: +62.4115856013.

E-mail: hasanbasri.phunhas@gmail.com

Acknowledgment: The authors re grateful to the enumerator team for obtaining data on the field and to other authors that helped in providing advice during the preparation of this study.

Key words: Moringa extract; supplementation; stunted.

Contributions: All authors contributed equally to this article and HB conducted to this study. Furthermore, VH contributed significantly to the arrangement of this article, while AZ, AS and RI participated in the review and gave recommendations before data was obtained in the field.

Conflict of interests: The author declares no potential conflict of interest.

Funding: This study was funded by the PMDSU research grant (Acceleration of Masters to Doctorate for Superior Scholars) Ministry of Education and Culture, Republic of Indonesia.

Ethic approval: This study received ethical approval from the Ethics Commission of the Faculty of Public Health, Hasanuddin University with Protocol Number: 5111993028 signed on letter number 10153 / UN4.14.7 / TP.01.02 / 2019

Conference presentation: Part of this study was presented at the $1^{\text {st }}$ International Nursing and Health Sciences Symposium, November $13^{\text {th }}$ to $15^{\text {th }} 2020$, Brawijaya University, Malang, Indonesia.

Received for publication: 14 January 2021.

Accepted for publication: 24 March 2021

oCopyright: the Author(s), 2021

Licensee PAGEPress, Italy

Journal of Public Health Research 2021;10:2207

doi:10.4081/jphr.2021.2207

This work is licensed under a Creative Commons Attribution NonCommercial 4.0 License (CC BY-NC 4.0).

\section{References}

1. International Food Policy Research Institute. Global Nutrition Report 2014: Actions and Accountability to Accelerate the World's Progress on Nutrition. Washington, DC: International Food Policy Research Institute; 2014.

2. Akombi BJ, Agho KE, Merom D, et al. Child malnutrition in sub-Saharan Africa: A meta-analysis of demographic and health surveys (2006-2016). PLoS One 2017;12:1-11.

3. Ministry of Health Republic of Indonesia. Basic Health Research 2018. Jakarta: Ministry of Health Republic of Indonesia; 2018.

4. Basri H, Hadju V. Breastfeeding and complementary food on nutritional status infants in Indonesia. Enferm Clin 2020;30:191-5.

5. Mahmud NU, Abdullah T, Arsunan AA, et al. Determinants of exclusive breastfeeding in 6 months old infant in Jeneponto District. Indian J Public Heal Res Dev 2019;10:1487.

6. Ramakrishnan U, Goldenberg T, Allen LH. Do Multiple micronutrient interventions improve child health, growth, and development? J Nutr 2011;141:2066-75. 
7. Fuglie LJ. The miracle tree: Moringa oleifera: natural nutrition for the tropics. Available from: https://agris.fao.org/agrissearch/search.do?recordID $=$ XF2015018648

8. Idohou-Dossou N, Diouf A, Gueye A, et al. Impact of daily consumption of Moringa (Moringa oleifera) dry leaf powder on iron status of Senegalese lactating women. Afr J Food Agric Nutr Dev 2011;11:4985-99.

9. Iskandar I, Hadju V, As 'ad S, et al. Effect of moringa oleifera leaf extracts supplementation in preventing maternal anemia and low-birth-weight. Int J Sci Res Publ 2015;5:1-3.

10. Muis M, Hadju V, Russeng S, et al. Effect of moringa leaves extract on occupational stress and nutritional status of pregnant women informal sector workers. Int J Curr Res Acad Rev 2014;2:86-92.

11. Nadimin, Hadju V, As S, et al. The Extract of moringa leaf has an equivalent effect to iron folic acid in increasing hemoglobin levels of pregnant women: A randomized control study in the coastal area of Makassar. Int J Sci Basic Appl Res 2015;22:287-94.

12. Hastuti, Veni H, Citrakesumasari, et al. Children's nutrition status 7-12 months based on age, education and job of their mother in South Sulawesi. Indian J Public Heal Res Dev 2019;10:1598.

13. Abdullah T, Bahar B, Jafar N, et al. Factors associated with the appropriate time of complementary feeding among infants in Jeneponto Districs South Sulawesi. Indian J Public Heal Res Dev 2019;10:1498-502.

14. Nurdin MS, Hadju V, Ansariadi, et al. The effect of moringa leaf extract and powder to haemoglobin concentration among pregnant women in Jeneponto regency. Indian J Public Heal Res Dev 2018;9:262-7.

15. Koletzko B, Godfrey KM, Poston L, et al. Nutrition during pregnancy, lactation and early childhood and its implications for maternal and long-term child health: The early nutrition project recommendations. Ann Nutr Metab 2019;74:93-106.

16. Shindu S, Mangala S, Sherry B. Efficacy of Moringa oleifera in treating iron deficiency anemia in women of reproductive age group. Int J Phyther Res 2013;3:15-20.

17. Shija AE, Rumisha SF, Oriyo NM, et al. Effect of Moringa oleifera leaf powder supplementation on reducing anemia in children below two years in Kisarawe District, Tanzania. Food Sci Nutr 2019;7:2584-94.

18. Saini RK, Manoj P, Shetty NP, et al. Dietary iron supplements and Moringa oleifera leaves influence the liver hepcidin messenger RNA expression and biochemical indices of iron status in rats. Nutr Res 2014;34:630-8.

19. Wasonowati C, Sulistyaningsih E, Indradewa D, et al. [Analisis fitokimia ekstrak daun kelor (moringa oleiferalamk) di madura].[Article in Indonesian]. Proc SEMNASDAL (Seminar Nas Sumber daya Lokal 2019;2:421-7.

20. Black RE, Victora CG, Walker SP, et al. Maternal and child undernutrition and overweight in low-income and middleincome countries. Lancet 2013;382:427-51.

21. Adair LS. Long-term consequences of nutrition and growth in early childhood and possible preventive interventions. Nestle Nutr Inst Workshop Ser 2014;78:111-20.

22. Zongo U, Zoungrana SL, Savadogo A, et al. Nutritional and clinical rehabilitation of severely malnourished children with Moringa oleifera leaf powder in Ouagadougou (Burkina Faso). Food Nutr Sci 2013;04:991-7.

23. Fahey JR. Moringa oleifera: A review of the medical evidence for its nutritional, therapeutic, and prophylactic properties. Trees Life J 2005;1:1-16.

24. Nnam NM. Moringa oleifera leaf improves iron status of infants 6-12 months in Nigeria. Int J Food Safety, Nutr Public Heal 2009;2:158.

25. Andrew A. Effect of moringa oleifera leaf powder supplement to improve nutritional status of severely malnourished children aged 6-24 months in Arusha region. Tanzania: Sokoine University of Agriculture; 2010.

26. Srikanth VS, Mangala S, Subrahmanyam G. Improvement of protein energy malnutrition by nutritional intervention with Moringa oleifera among Anganwadi children in rural area in Bangalore, India. International J Sci Study 2014;2:32-5.

27. Gbadebo AO, Okareh OT, Ogunjobi AA, et al. Effects of Moringa oleifera lam. leaf powder on bifidobacteria and escherichia coli in the gut of albino rats. J Adv Microbiol 2019;18:1-11.

28. Khuzaimah A, Hadju V, As S, et al. Effect of honey and Moringa oleifera leaf extracts supplementation for preventing DNA damage in passive smoking pregnancy. Int J Sci Basic Appl Res 2015;24:138-45.

29. Karmila S, Saifuddin S, Tahir A, et al Determinant factors affecting the development of motor, cognitive and socioemotional children ages 18-12 months in the District Jeneponto, Indonesia. Indian J Public Heal Res Dev 2019;10:1564.

30. Prado EL, Larson LM, Cox K, et al. Do effects of early life interventions on linear growth correspond to effects on neurobehavioural development? A systematic review and metaanalysis. Lancet Glob Health 2019; 7:e1398-413. 